\title{
Washington Hottine
}

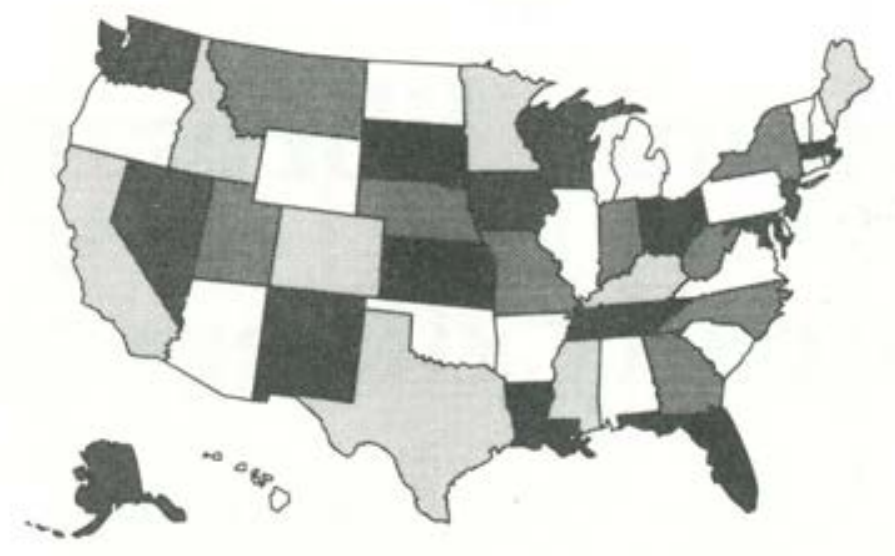

Carol C. Henderson

(202) 547-4440; (ALA0025)

Deputy Director, ALA Washington Office

Copyright, unpublished works. Bills to clarify that the fair use doctrine incorporated in section 107 of the copyright law applies to unpublished as well as published copyrighted works were introduced in March by Rep. Robert Kastenmeier (D-WI), Chairman of the Judiciary Subcommittee on Courts, Intellectual Property, and the Administration of Justice, and by Sen. Paul Simon (D-IL) and Sen. Patrick Leahy (D-VT), both members of the Senate Judiciary Committee.

The bills, HR 4263 and S. 2370, are a response to federal court rulings which have the effect of severely restricting authors and scholars from quoting excerpts from unpublished primary sources, or requiring permission for all such use. The quoting of reasonable excerpts had long been considered fair use. Most recently, the Supreme Court in February declined to review a 1987 Second Circuit Court of Appeals decision in New Era Publications v. Henry Holt, which found that an author's copyright in unpublished works is infringed by the subsequent quoting of excerpts in works such as biographies.

Copyright, software. On May 1, the Senate passed S. 198, a bill to prohibit the commercial rental, lease, or lending of computer software. S. 198 would exempt nonprofit libraries and nonprofit educational institutions from its provisions. Nonprofit libraries lending software must affix to each software package the following notice:

"Warning: This computer program is protected under the copyright law. Making a copy of this program without permission of the copyright owner is prohibited. Anyone copying this program without permission of the copyright owner may be subject to payment of up to $\$ 100,000$ damages and, in some cases, imprisonment for up to one year."

The Register of Copyrights is to review the library exemption in three years, and after consulting with copyright owners and librarians, report to Congress. In other provisions, transfer of possession of a lawfully made copy of computer software by a nonprofit educational institution among faculty, staff, students, or to another school is not prohibited. The bill does not apply to computer programs embodied in computer game cartridges.

The Senate Judiciary Committee's April 19 report (S. Rept. 101-265) on S. 198 includes a section on "Lending by Libraries and Educational Institutions," from which the following is excerpted: "...many educational institutions legally acquire copies of computer programs for use by multiple users. Examples of this include the lending by instructors to students of programs to be used by the student in completing a class assignment. This practice or other practices involving the transfer of possession of an authorized copy of a computer program owned by an educational institution among faculty, students, and staff for individual use, or to another nonprofit educational institution, which does not involve the making of unauthorized copies, does not constitute rental, lease or lending for direct or indirect commercial purposes under this act." 